\title{
Mainstreaming international governance: The environment, gender, and IO performance in the European Union
}

\author{
Mark A. Pollack • Emilie M. Hafner-Burton
}

Received: 2 July 2010 / Revised: 11 July 2010 / Accepted: 12 July 2010 /

Published online: 31 July 2010

(C) The Author(s) 2010. This article is published with open access at Springerlink.com

\begin{abstract}
International organizations (IOs) have moved increasingly in recent years to adopt cross-cutting mandates that require the "mainstreaming" of particular issues, such as gender equality or environmental protection, across all IO policies. Successful IO performance with respect to such mandates, we hypothesize, is determined in large part by the use of hard or soft institutional measures to shape the incentives of sectoral officials whose cooperation is required for successful implementation. We test this hypothesis with respect to two such mandates-gender mainstreaming and environmental policy integration - in a single international organization, the European Union, demonstrating a strong causal link between the use of hard incentives and IO performance in these and related mandates.
\end{abstract}

Keywords International organizations · European Union · Cross-cutting mandates · Environmental policy $\cdot$ Gender mainstreaming $\cdot$ Impact assessment

JEL Classification F51 F55

\section{Introduction}

International organizations (IOs) today are not just growing in number, they are also undertaking expanded mandates to include more and more cross-cutting issues in governance, including most notably the "greening" of public policy and the "mainstreaming" of gender and other policy concerns across all units of the IO

M. A. Pollack ( $\bowtie)$

Department of Political Science, Temple University, 461 Gladfelter Hall, Philadelphia, PA 19066, USA

e-mail: mark.pollack@temple.edu

E. M. Hafner-Burton

Department of Political Science, University of California at San Diego, 9500 Gilman Dr., 0519,

La Jolla, CA 92093, USA

e-mail: ehafner@ucsd.edu 
and all stages of the policy process. At one level, this development of new, crosscutting mandates is encouraging, illustrating an increasing responsiveness of IOs to member governments and other stakeholders, and mirroring the development of horizontal mandates and "joined-up governance" in domestic policymaking.

The growing phenomenon of cross-cutting mandates, however, also raises questions about the ability and willingness of international organizations, and the various sectoral sub-units that make them up, to implement such mandates effectively. Not surprisingly, performance varies widely across organizations and can be incomplete or superficial; IOs that take on ambitious issues like the environment or gender equality rarely put these agreed-upon objectives into deep institution-wide practice. The results may be partial, shallow, or short-term policy outcomes that fall short of meaningful implementation or function as window dressing. Put simply, the global diffusion of cross-cutting mandates like gender mainstreaming and "environmental policy integration" (EPI), which constitutes a normative theme of contemporary international governance, coexists with dramatic variation in the performance of IOs in implementing such cross-cutting mandates. Barring effective IO performance (IOP), there is no guarantee that the nearly universal adoption of such mandates will result in the achievement of their putative goals.

The problem, we argue, lies in the failure of organizations to mobilize sufficient interest among crucial actors, beginning within the bureaucracy of the IO in question. The challenge for IOs is to motivate their bureaucrats to conform to crosscutting mandates even when, for reasons of organizational culture or bureaucratic self-interest, they prefer not to. We hypothesize that IOs perform better-are more successful in achieving their stated objectives - when they provide "hard" incentives for relevant bureaucrats to implement reforms, whether through carrots (positive incentives) or sticks (negative incentives). IOs are less successful when they depend exclusively on "soft" incentives such as persuasion and socialization of the bureaucrats in question. This does not mean that attempts at persuasion and socialization are futile, but the success of such efforts is likely to be at best selective, succeeding only insofar as a proffered policy frame "resonates" with officials' existing world-views (Pollack and Hafner-Burton 2000), or produces "win-win" outcomes in which the acceptance of a cross-cutting mandate coincidentally delivers benefits to sectoral policymakers (Lenschow 2002b). Because cross-cutting mandates require implementation across many different issue-areas and units within IOs, however, such outcomes are often difficult to achieve. This is particularly true in an IO like the European Union (EU), which takes in a large number of sectoral policies and is deeply "pillarized," with strong sectoral Directorates-General (DGs) and with an intergovernmental Council of Ministers also organized along sectoral lines (Jordan et al. 2008: 161, Hartlapp 2011). As a result, we argue, global norms such as gender mainstreaming or environmental policy integration are most likely to change the substance of IO policy when their implementation serves elite bureaucratic self-interest.

In this article, we offer a simple theory of IO performance on cross-cutting mandates, and test our hypothesis with respect to two such mandates-gender mainstreaming and environmental policy integration - in a single international organization, the European Union. In both cases, we demonstrate, the common use of soft incentives has produced highly variable, selective, and (from a normative 
perspective) disappointing "take up" of the respective mandate by sectoral IO officials. Our story does not end with this comparison, however. Within each case, we identify closely related cross-cutting mandates - equal opportunities policy with respect to gender, and the recently adopted impact assessment (IA) system with respect to the environment - each of which features greater use of hard incentives, and each of which has demonstrated rapid, measurable progress in IO performance.

This article is organized in five parts. Following this introduction, the second section locates our approach in the collective theoretical framework of the IOP project (Gutner and Thompson 2010), and articulates our core hypothesis about the effectiveness of hard and soft incentives in securing IO performance on cross-cutting mandates.

In the third section, we analyze the empirical record of gender mainstreaming in the European Commission, examining policy processes and policy outputs across the full range of Commission activities. Specifically, we detect a highly variable and voluntaristic pattern of extensive gender mainstreaming by selected DGs and scant activity by others. This variable record of implementation, we argue, is due largely to the Commission's reliance on soft incentives. Outside of a small number of pioneering DGs, we find, efforts to socialize and persuade reluctant officials to "take gender seriously" have failed to significantly change behavior. An implicit counterfactual in our argument is that hard incentives would lead to more consistent implementation of mainstreaming across DGs. While we cannot test this claim directly, the conclusion of this section offers a brief comparative study of another gender-related mandate: the Commission's Fourth Action Program on Equal Opportunities for Men and Women in the Commission, which focuses on the recruitment, retention and treatment of qualified women officials. Early action programs in this area also employed soft measures, resulting in only marginal improvements in most DGs by the early 2000s. But the Fourth Action Programme, introduced in 2004, incorporated the use of hard incentives, resulting in rapid, quantifiable improvement across virtually all DGs. Hence, within the broad area of gender politics, we find variation in both process and outcome between the gender mainstreaming and the equal opportunities mandates, in ways that support our core argument.

In the fourth section, we examine the case of environmental policy integration. Beginning in the 1980s, the European Commission articulated a doctrine of EPI, and in 1993 the Commission instituted a program that, as in the gender case, relied primarily on soft incentives. The result was a highly variable and generally disappointing take-up of the EPI mandate, which failed to produce substantial changes in policy outputs even among priority sectors like energy and transport. By the end of the decade, the Union had adopted a new approach that sought to carry EPI beyond the Commission bureaucracy to EU member governments through the so-called "Cardiff process." Here again, however, the incentives for sectoral policy actors to prioritize environmental concerns were negligible, and within just a few years this initiative fell into disuse. Following this second failure, the Union's most recent Environmental Action Program experimented further, seeking to develop cross-sectoral "Thematic Strategies," linking the environment into the Union's "Lisbon Strategy" on jobs and growth, and incorporating environmental considerations alongside others in a new impact assessment procedure. Most of these efforts also relied on soft, "new governance," mechanisms, severely limiting their impact on policy 
outcomes. The striking exception is the impact assessment procedure, which has been imposed through a series of increasingly strict, centralized, and enforced guidelines, with early signs of improved performance over time. This finding, we argue in the fifth and concluding section, strongly supports our hypothesis about the causal linkage between hard incentives and policy outputs, yet it also focuses our attention on the problem of institutional choice, whereby states and other actors opt for institutional frameworks that are more - or less-likely to effectively mainstream putative policy concerns across all IO policies.

\section{Cross-Cutting Mandates and IO Performance: Getting the Incentives Right}

Gutner and Thompson (2010), in their framework article for this special issue, focus on two fundamental challenges of studying IO performance, namely the measurement of performance and the explanation of the sources of performance. On the issue of measurement, the authors offer a continuum of metrics, ranging from (1) processbased or micro indicators of narrow IO functions, through (2) "intermediate" indicators of behavior and policy agendas in IOs, to (3) the "macro" level of problem resolution and welfare enhancement. We call these three metrics "process," "output," and "outcome," respectively. Like Gutner and Thompson, our primary interest is in the performance, not of entire regimes, but of IOs understood as collective actors and agents of member-state principals (Hawkins et al. 2006).

In empirical terms we examine IO performance in response to two specific mandates, the first to mainstream gender, and the second to integrate environmental issues, across the full range of policies in IO policymaking. ${ }^{1}$ Gender mainstreaming has been defined as "the (re)organisation, improvement, development and evaluation of policy processes, so that a gender equality perspective is incorporated in all policies at all levels and at all stages, by the actors normally involved in policymaking" (Council of Europe 2008: 1). The definition of environmental policy integration is somewhat more disputed by practitioners and scholars, but here too the essence of the concept is that environmental concerns are integrated into sectoral policies such as agriculture, energy, and transport, which have large potential impacts on the environment, but which have traditionally been formulated with little or no regard to environmental concerns (Lenschow 2002b).

The prospect of such cross-cutting mandates is both potentially revolutionary and extraordinarily demanding. Both mandates could transform the full range of EU public policies to promote the Union's principled objectives - but only if a wide range of actors change their behavior. This involves two components: a "horizontal" mainstreaming of issues by policy-makers across various issue-areas at the EU level; and a "vertical" integration of policy-making activities between EU institutions and national governments. So conceived, a cross-cutting mandate in the EU or in any other political system should in principle result in developments at all three levels: process, outputs, and outcomes.

\footnotetext{
${ }^{1}$ Although the two terms, mainstreaming and integration, are generally used in their specific gender or environmental contexts, we regard them as synonymous, and shall use them interchangeably.
} 
Ultimately, both scholars and activists are most interested in policy outcomes - the impact of mainstreamed public policies on social and environmental outcomes "on the ground" in an IO's member states. However, as Gutner and Thompson (2010) argue, measuring IO performance through outcomes is both methodologically demanding and risks conflating the actions of member states with the performance of particular IOs. Given these difficulties, much of the previous literature on various cross-cutting mandates has focused instead on process. In these studies, the success of a given mandate is judged according to the tools and procedures used to mainstream particular issues in the policy process (Hafner-Burton and Pollack 2002).

There are shortcomings, however, to a purely process-based assessment, because even an elaborate process may in practice fail to produce "mainstreamed" sectoral policies. For this reason, we believe the most reliable measure of successful mainstreaming is in the policy outputs of departments, ministries, or-in our casethe 41 Directorates-General and services of the European Commission, which acts as the primary agenda-setter and enforcer of EU policies.

Thus the dependent variable of our study is the policy outputs of the various Commission DGs and services, with a focus on the extent to which those policies are explicitly formulated to address gender inequality and environmental concerns, respectively. Our hypothesized independent variable is the nature of Commissionwide processes used to mainstream cross-cutting policy considerations throughout the organization, especially the use of hard or soft incentives.

Having discussed measurement issues, Gutner and Thompson go on to identify various theoretical explanations for variation in IO performance. They point out that the existing literature consists largely of "external-material" theories (such as principal-agent analysis) which adopt a materialist ontology but focus on contextual factors outside IOs, and "internal-social" analyses (such as organizational sociology) which adopt a cultural or ideational ontology but focus on the internal workings of IOs. By contrast, our analysis combines a rationalist set of assumptions about actors and their preferences with a primary focus on the internal politics of IOs such as the European Commission. ${ }^{2}$

We stipulate, as in rationalist models of bureaucratic politics, that the Commission is a complex bureaucracy, divided into ministry-like DGs and services, each characterized by a distinctive set of policy preferences and expertise. These DGs are potential bottlenecks in the integration of a gender or environmental perspective across all policy areas. The challenge for any cross-cutting mandate is to motivate "the actors normally involved in policy-making," although these actors may consider gender or environmental issues to be irrelevant or even a hindrance to their core policy goals. In this sense, cross-cutting mandates represent a variant of the classic principal-agent problem, in which a principal-in this case the College of Commissioners at the top of the Commission hierarchy—-seeks to alter the behavior of thousands of officials or fonctionnaires across dozens of DGs and services. The challenge, in principal-agent terms, is to "get the incentives right."

\footnotetext{
${ }^{2}$ Although our approach is rationalist, we would reject a purely "materialist" label for our analysis. Although we place significant emphasis on material incentives in our study, we believe that the use of social pressure-designed to impose social costs and benefits on actors even in the absence of socialization or persuasion (Johnston 2001) — is fully consistent with our rationalist assumptions.
} 
The behavior of IO officials could be altered, in theory, through one of two types of institutional measures. Following Abbott and Snidal (2000), we refer to these in terms of "hard" and "soft" incentives, with the former establishing precise, binding and enforceable rules, while the latter employ less precise, non-binding guidelines and voluntary compliance. Hard measures, for example, could materially influence the incentives of IO officials by making individual pay or promotion dependent upon successful mainstreaming of sectoral policy outputs. Somewhat further down the continuum toward soft incentives would be the use of social pressure, or "naming and shaming" exercises, in which both leaders and laggards in mainstreaming would be publicly identified and praised or shamed for their performance.

Nevertheless, hard instruments are not the most commonly used method for promoting the implementation of cross-cutting mandates in either IOs or governments. In recent years, scholars have emphasized the prospects for deliberation, socialization and persuasion within IOs (Risse 2000, Checkel 2005). The empirical literature generated by these claims has produced at best weak evidence of such socialization effects (Schimmelfennig and Sedelmeier 2005, Zürn and Checkel 2005), and Liesbet Hooghe (2001) in particular has demonstrated the difficulty of socializing European Commission officials whose prior, national-level attitudes are often well established in comparison with their relatively "thin" Commission socialization. Socialization efforts related to cross-cutting mandates face a still greater hurdle, since they often take the form of occasional cross-departmental encounters whose central message may cut against the organizational mission of a given official's home DG as well as their life-long professional training.

Despite these obstacles, both scholars and practitioners have placed considerable stock in the prospects for persuasion and socialization in the implementation of cross-cutting mandates. Catherine Weaver (2008: 15), for example, has documented a belief among many World Bank officials that the exclusive use of hard incentives is likely to result in superficial compliance, while a sustained process of persuasion and socialization is more likely to lead to internalization and long-term compliance. Similarly, many EU Commission officials we interviewed expressed a preference for the long-term process of training, awareness-raising, and socialization, believing it yields more consistent implementation even though, as they often emphasized, it takes time. ${ }^{3}$

We do not disagree that a well-designed, long-term process of socialization could eventually lead to the diffusion and internalization of specific policy concerns among diverse IO officials. Even where hard incentives provide the primary motivation for actors to change their behavior, the specific nature of those changes may be guided, at least at the margins, by socialization and learned norms. Nevertheless, given the well-documented obstacles to such socialization, we hypothesize that cross-cutting mandates are most likely to be successful-that is, to integrate the desired perspective into internal IO procedures and produce measurable policy outputs - when the mandates use hard, binding instruments to alter the incentives for IO officials even in the absence of any successful persuasion or socialization.

To test our hypothesis about the effectiveness of hard incentives in IO performance, we analyze two case studies of cross-cutting mandates in the EU,

$\overline{3}$ Interviews, Commission officials, Brussels, 28 November 2007, and 2 April 2008. 
gender mainstreaming and EPI, examining in each case both the processes put in place to diffuse gender and environmental concerns across the entire organization, and the pattern of policy outputs from the various DGs and services. In each case, we also examine a closely related mandate-equal opportunities and impact assessment, respectively - characterized by harder incentives, and assess policy outputs in these areas. In doing so, we engage in both congruence analysis, looking for the predicted correlation between incentives and policy outputs, and also in process-tracing, identifying causal mechanisms linking incentives and outputs in each area (George and Bennett 2005). In the case of gender mainstreaming, which has been subject to relatively few scholarly studies, we rely primarily on official Commission documents, on our own original coding of policy outcomes, and on extensive Brussels-based fieldwork over the course of a decade. The case of environmental policy integration, by contrast, has been the study of an extensive scholarly literature, ${ }^{4}$ and we draw on this literature, as well as on primary EU sources, to trace the complex history of EPI and its variable outcomes over the years.

\section{Gender Mainstreaming}

As is now well known, the European Economic Community (EEC) did not begin as an organization devoted to sexual equality, and lacked an explicit mandate to engage in gender equality policy. ${ }^{5}$ However, the 1957 EEC Treaty did contain a provision requiring equal pay for equal work for men and women. Although there is little evidence that member governments negotiating the treaty intended for this provision to be directly effective, the European Court of Justice ruled exactly that in a series of rulings from the 1970s. Following up on this effort, the Commission proposed, and the Council of Ministers adopted, a series of relatively progressive directives setting minimum standards for equal pay and equal treatment of men and women in the workplace. By the early 1990s, the EU had clearly emerged as a progressive force for sexual equality in the member states, although critics pointed out that the EU's promotion of sexual equality was essentially limited to the treatment of women in the workplace, and seldom extended beyond that to address the broader causes and consequences of sexual inequality (Hoskyns 1996).

It was in this context that the concept of gender mainstreaming entered the mainstream of international public policy in September 1995, when it featured in the Platform for Action of the Fourth World Conference on Women in Beijing. The term

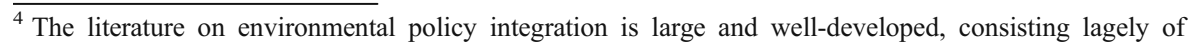
qualitative, case-study analyses, many of them conducted in the context of the EU-funded EPIGOV program (Environmental Policy Integration and Multi-Level Governance, http://ecologic.eu/projekte/ epigov/index.htm), which has also compiled an excellent literature review on the subject (Herodes et al. 2007). For excellent general introductions to EPI in the EU, see, e.g., European Environment Agency (2005), Lenschow (2002a), Jordan and Lenschow (2008), Jordan et al. (2008), Nilsson and Eckerberg (2007), Persson (2004), and Wilkinson (1997, 2007). See also the related scholarly literature on the "greening" of development lending, e.g., Gutner (2002) and Nielsen and Tierney (2003), which demonstrate the parallel challenges of integrating environmental policy concerns in other international organizations.

${ }^{5}$ This section draws on our previous work, including Pollack and Hafner-Burton (2000), Hafner-Burton and Pollack (2002), and especially Hafner-Burton and Pollack (2009).
} 
gender mainstreaming had in fact first appeared in the 1980s in the international development community, and had entered EC parlance in 1991, when it appeared as a relatively small but innovative element in the Third Action Programme on Equal Opportunities (1991-1996). Following the Beijing Conference, the European Commission seized a leadership role in this area, declaring in February 1996 a commitment to mainstream all Community policies for the purpose of promoting gender equality (Commission 1996a).

\subsection{Soft Instruments, Weak Incentives}

The first question, for our purposes, was whether the Commission would implement its new mainstreaming mandate using hard or soft incentives for its officials in the various sectoral DGs. A "hard" gender mainstreaming program, we suggest, would score high on Abbott and Snidal's (2000) three dimensions of obligation, precision, and delegation, with (a) binding provisions entailing (b) precise responsibilities and commitments for Commission officials, backed by (c) strictly enforced positive and negative sanctions for compliance and noncompliance. By contrast, a "soft" mainstreaming program would be characterized by (a) non-binding provisions with (b) vague or imprecise aims and (c) little or no attempt to monitor and sanction officials for compliance and noncompliance.

More specifically, the gender mainstreaming tool kit can be arrayed along a continuum from soft to hard, including, inter alia, the establishment of coordinating committees or networks of gender-mainstreaming officials; collection of genderdisaggregated statistics; checklists, manuals and handbooks; gender training; gender impact assessment of policies; post-hoc monitoring and evaluation of policies; and enforcement of policy through sanctioning of public officials at both the Commission and member-state levels (Hafner-Burton and Pollack 2002). In the case of the EU, the institutional machinery and procedures put in place by the Commission fall overwhelmingly at the "soft" end of the spectrum. They feature a vague overall mandate, a heavy emphasis on non-binding instruments like networking and training, and little or no monitoring, public reporting or enforcement.

At first glance, the EU's official documentation enumerates an impressive series of cross-departmental networks and working groups established at various levels, including a "Commissioners Group" intended to coordinate the mainstreaming mandate at the highest level, as well as an Inter-Service Group on Gender Equality charged with implementing gender mainstreaming within the Commission bureaucracy, with a weak coordination role for the Equal Opportunities Unit of DG Employment and Social Affairs.

In practice, however, the soft character of the mandate for these groups is readily apparent. For example, the Commissioners Group was intended to meet quarterly, but met only once during 2007, and has offered little meaningful guidance to the bureaucracy, according to Commission officials. At a lower level, the Inter-Service Group on Gender Equality has continued to meet on a regular basis, three to four times per year, to discuss experiences and best practices, yet these meetings have been attended largely by low- or mid-level officials from the various DGs. The result, according to participants, is a network of like-minded and well-informed but 
relatively low-level officials who lack the influence within their DGs to overcome resistance to what is often perceived as an intrusive and irrelevant mainstreaming mandate. In the words of one Commission official, "these are the poor sods who have to go back and nag at the hierarchy." "Other soft instruments, including most notably training, have proven similarly disappointing. While some DGs have introduced mandatory gender training for some or all of their officials, the bulk of gender training offered within the Commission has been voluntary, and attended largely by low-level officials.

By contrast with these soft instruments, hard incentives have been scant from the beginning, and actually appear to have weakened over time. In terms of reporting, for example, in 1998 the Inter-Service Group compiled what was intended to be the first of a series of annual reports on the implementation of gender mainstreaming (Commission 1998a), yet this effort was discontinued after a single year, and the Commission imposed no mandatory reporting requirement on the DGs, nor does it publish such information in an effort to "name and shame" individual DGs.

Our interviews with Commission officials across several DGs confirm this absence of hard incentives. Asked explicitly whether Commission officials had strong incentives to incorporate gender into their daily policy-making activities, one official in DG EMPL answered, "No, not really." For a Commission fonctionnaire preparing a policy or a draft decision, this official continued, "gender's not going to be the reason why your thing goes up or down." Another official concurred, saying officials felt "no particular pressure" to integrate gender in external-relations policies. If the Commission wanted to move beyond such a voluntary approach, she continued, the gender-mainstreaming mandate should be mandatory and "included in rules." 8

We should, of course, beware of relying too heavily on the views of a few Commission officials about the prerequisites for successful gender mainstreaming. Nevertheless, the remarkable consistency of such views among Commission officials in our own research and in Schmidt's (2005) study of mainstreaming in two Commission DGs predicts a pattern of policy outputs that are highly variable by sector, falling well short of the ideal type of mainstreaming across all sectors and DGs. And this is indeed what we find.

\subsection{Policy Outputs in Sectoral DGs}

Early studies of mainstreaming in the Commission found that the new mandate had been taken up most readily by a few "pioneer" DGs - including DG Employment, Social Affairs and Equal Opportunities, DG Development, DG Regional Policy and DG Research — several of which had already begun to address gender issues prior to the 1996 mandate (Pollack and Hafner-Burton 2000). The Commission's public commentary on gender mainstreaming similarly acknowledges that "best practice" is clustered in just a few sectors, with little or no evidence of effective mainstreaming in most other areas of EU competence (Commission 2008c).

\footnotetext{
${ }^{6}$ Interview, Commission official, Brussels, 28 November 2007.

${ }^{7}$ Interview, Commission official, DG Employment and Social Affairs, Brussels, 28 November 2007.

${ }^{8}$ Interview, Commission official, DG Development, Brussels, 28 November 2007.
} 
Our interest here is to assess whether a gender perspective has diffused beyond these pioneer DGs to the rest of the Commission and to all issue-areas in EU policymaking. To do so, we have identified (Hafner-Burton and Pollack 2009) two imperfect measures of gender-related activity. The first draws on the Commission's annual "work program" on gender equality, while the second examines the annual reports filed by the DGs and posted on the Commission web site.

The first of these sources, the Commission's annual internal "work programs" for gender equality policy (Commission 2007a, 2008a), usefully include detailed annexes that identify each gender-related activity, note the actions taken during the previous year, and identify the DG or service responsible for the specified activity. To create an index of gender-related policy outputs, we drew upon the Commission's 2007 and 2008 work programs, identifying for each DG the total number of activities actually carried out during the previous year. The results are striking. Taking 2007 (the most recent year for which figures are available) as a benchmark, we find no activities mentioned for 17 of the 41 DGs and services listed on the Commission's website, while 15 DGs and services list one or two activities each. The bulk of the activities come from DG Employment and Social Affairs, which alone accounts for 40 of the 91 activities reported for 2007 , or $44 \%$. The remaining six DGs, which reported between three and eight activities each, include DG Education and Culture with eight; DG Development and EuropeAid, which represent the two successors to the original DG Development and together account for eight activities; DG Research, with five; DG Justice, Freedom and Security, also with five; and DG Regio, with three (Hafner-Burton and Pollack 2009: 134-138).

As a second indicator, we consulted the annual reports issued by each DG and service in the Commission and made publicly available on the Commission website. These reports are a cruder indicator than the Commission's work programs, but nevertheless provide a sense of the political importance the DGs place on gender issues. We therefore surveyed the reports of each of the DGs and services, looking for discussion of gender, women, sexual equality and equal opportunities in the public policies of each unit. We find that relatively few DGs and services mention gender issues, with only 11 of 41 reports (or $27 \%$ ) mentioning women or gender in their respective policies. By and large, the DGs with the largest number of activities in the work programs are also those that give greatest prominence to gender in their annual reports (Hafner-Burton and Pollack 2009: 134-138).

Taken together, these data support the view that Commission DGs and services have shown sharp variation in their performance in response to the gendermainstreaming mandate. Several DGs have adopted and implemented strikingly progressive gender policies in areas such as employment, development, education, and research, and have shown modest progress over time. Nevertheless, it is clear that the gender mainstreaming mandate has been enthusiastically accepted by just a few leading DGs, which continue to account for the vast bulk of EU activities.

These findings receive strong support from our own qualitative, interview-based research, as well as from recent scholarship and non-governmental organizations. Verena Schmidt (2005), for example, has demonstrated that mainstreaming was poorly understood and even more poorly implemented in several key DGs, while Maria Stratigaki (2005) criticized the mainstreaming mandate for drawing resources and attention away from existing and effective policies on gender equality and 
replacing them with a vague mandate that most DGs have implemented weakly or not at all. Along similar lines, the European Women's Lobby (2007: 1) has grown increasingly critical of gender mainstreaming, citing insufficient budgeting, impact assessment and training for Commission officials, and the failure "to involve all services in the Commission." In sum, while individual Commission DGs have implemented a number of progressive gender policies over the past decade, the performance of the Commission as a whole demonstrates at best partial progress towards a genuine mainstreaming of gender issues across all units and all issue-areas.

\subsection{Equal Opportunities Policy and the Power of Hard Incentives}

In our interviews with Commission officials, we were struck that several officials noted a marked contrast between the weakness of the gender mainstreaming mandate and the greater success of a second cross-cutting mandate, also related to gender: the Fourth Action Program for Equal Treatment for Men and Women in the European Commission. As early as the 1980 s, the Commission had recognized as a problem the large gender imbalance among Commission officials, and instituted three "Action Programs," in 1988-1990, 1992-1996, and 1997-2000, using soft incentives to encourage greater recruitment and retention of women officials among high-level Commission managers, with meager results.

The issue of equal opportunities received a new impetus, however, in the early 2000s, when Commission Vice President Neil Kinnock ordered a top-to-bottom review of internal Commission procedures. A resulting external evaluation of the Third Action Program was largely critical, finding little evidence of positive changes to reduce the conflict between professional and personal commitments, as well as "a serious lack of consistency across DGs in the implementation of the 3rd Programme" (Commission 2004a: 4-6). In light of these findings, Kinnock concluded that, "A 4th Action Programme, with quantifiable measures that would be regularly monitored and whose implementation could be compared across DGs, is... the best means of ensuring that appropriate priority is given to equal opportunities policies in the different DGs and services" (Commission 2004a: 5). In the years that followed, the Commission moved to put in place a new program, based on quantitative targets, mandatory reporting, and social and material sanctions for individual DGs, with a strong coordinating role for DG Personnel and Administration, or ADMIN.

Within each DG, the new program assigned responsibility to a senior official and included it in his/her job description, and directed the creation of an Equal Opportunities Group to prepare and implement a gender action plan. DGs were also required to monitor the implementation of their action plans and submit an annual report to DG ADMIN, which would co-ordinate the implementation, monitoring and evaluation of the program; publish an annual assessment of its progress; establish a ranking of best performing DGs; and launch an external evaluation at the end of the program (Commission 2004a: 15).

Thus the Commission's Fourth Action Program on Equal Opportunities broke sharply with previous action programs and with the Commission's mainstreaming mandate by introducing a wide range of "hard" incentives that were precise and obligatory. Just as importantly from our perspective, both Kinnock, and his successor, Siim Kallas, vigorously enforced the provisions of the program vis-à-vis 
the various DGs and services, with reports that publicly named and shamed the best and worst performing DGs and imposed binding recruitment targets for seriously underperforming DGs (Commission 2007b, 2008b).

These and other measures, the Commission reported, resulted in substantial improvement in compliance virtually across the board. "The overall assessment," the Commission concluded, was that "the binding measures adopted by the Commission are being introduced correctly, that the DGs are complying with them and that they already appear to be producing positive results" (Commission 2007b: 3). For example, results for 2007 demonstrated progress in recruitment, where targets were for the first time met or exceeded in all three categories: $35.1 \%$ female appointments to senior management, $31.5 \%$ to middle management, and $54.2 \%$ to $\mathrm{AD}$ nonmanagement posts (Commission 2008b: 1).

The effectiveness of hard incentives in the Fourth Action Program was also underlined to us repeatedly in interviews with Commission officials. For example, one DG Development official suggested the contrast at the very beginning of our interview. Unlike the mainstreaming language, she said, the equal opportunities mandate included specific targets and indicators, which are "the only thing at the end of the day that makes a difference." The most successful efforts, she said, are "harddata things" and "mandatory things," which tend to get done; all the rest are just "nice talking." Another Commission official, in DG Employment, suggested that Kallas had made a very deliberate decision to release reports naming and shaming DGs for their insufficient recruitment of women, and said it was "horrible for a chef $d u$ cabinet to have to explain to their Commissioner that they were one of the worst." $" 10$

In sum, both the mainstreaming and the equal opportunities initiatives represent cross-cutting mandates, introduced in the same organization at approximately the same time. Both sought to influence and change the behavior of officials in a wide range of Commission DGs and services. Both mandates initially relied exclusively on soft incentives, to generally disappointing results. By contrast with the gender mainstreaming mandate, however, the equal opportunities mandate introduced hard incentives after 2004, resulting in a rapid improvement in IO performance in subsequent years. The equal opportunities case, we argue, vividly illustrates the successful use of hard incentives, including (a) procedural requirements (naming high-level coordinators and committees, and drafting an explicit action program), (b) reporting requirements (annual reports submitted to the program coordinator), and (c) the prospect of positive and negative sanctions (naming and shaming, and the imposition of mandatory targets) - all of which were potentially transferrable to other cross-cutting mandates in the Commission and beyond.

\section{Environmental Policy Integration}

As in the case of gender, the 1957 EEC Treaty made no mention of environmental protection, and conferred no explicit legal competence to the EC to engage in

\footnotetext{
${ }^{9}$ Interview, Commission official, DG Development, Brussels, 28 November 2007.

${ }^{10}$ Interview, Commission official, DG Employment and Social Affairs, Brussels, 28 November 2007.
} 
environmental regulation. Relatively quickly, however, EC member states discovered that national environmental regulations could and did act as non-tariff barriers to intra-EU trade, and over the course of the next several decades, the Commission proposed, and the Council of Environment Ministers and European Parliament adopted, a series of non-binding Environmental Action Programs (EAPs) and a growing body of legally binding environmental Regulations and Directives. By the end of the 1980s, the Single European Act had conferred formal competence on the EU to engage in environmental regulation, and the EU had arguably emerged as the most progressive environmental regulator in the world (Lenschow 2010).

Nevertheless, for our purposes here, it is striking that these early efforts at environmental regulation were largely confined to a small sectoral community of environmental policy-makers centered around the Commission's DG Environment, the Council of Environment Ministers, and the European Parliament and its committee on environmental affairs. To some extent, this sectoral isolation proved a boon to EU environmental regulation, since EU environmental policymakers were able to adopt progressive regulation without interference from sectoral officials who might otherwise have acted as veto players and blocked or watered down proposed regulations (Hartlapp 2011). Yet this same fragmentation of the EU policy process also limited the prospects for integrating environmental considerations into other areas like agriculture, transport, and energy, which had major impacts on the environment, but over which environmental policy-makers exerted little influence (Jordan et al. 2008).

\subsection{From Environmental Policy to EPI, 1983-1992}

The Commission, and particularly DG Environment, was well aware of this dilemma, and proposed, with increasing explicitness over the years, the integration of environmental concerns into sectoral policy-making. In 1983, in its third Environmental Action Program (EAP), the Commission (1983) made its first explicit call for what came to be called environmental policy integration:

The Community should seek to integrate concern for the environment into the policy and development of certain economic activities as much as possible and thus promote the creation of an overall strategy making environmental policy part of economic and social development. This should result in a greater awareness of the environmental dimension, notably in the fields of agriculture (including forestry and fisheries), energy, industry, transport and tourism.

This call was reiterated in the 4th EAP, which announced that the Commission would "develop internal procedures and practices to ensure that the integration of environmental factors takes place routinely in relation to all other policy areas" (Commission 1987: para. 2.3.28), and in the 5th EAP, which explicitly identified five key issue-areas - industry, energy, agriculture, transport and tourism-where policy integration seemed most urgent (Commission 1993a).

The Commission's efforts during this period were bolstered by the progressive inclusion and strengthening of the EPI principle in the treaties over the course of the 1980s and 1990s - a development encouraged by the Commission and championed by environmental leaders among the EU's member governments. In the 1987 Single 
European Act, the member states collectively amended the founding EC Treaty to incorporate EPI, with Article 130r(2) establishing that "environmental protection requirements shall be a component of the Community's other policies." Six years later, the Maastricht Treaty amended the existing treaty further, calling in Article 2 for "sustainable and non-inflationary growth respecting the environment," while strengthening the integration principle in Article 130r(2) to provide that, "Environmental protection requirements must be integrated into the definition and implementation of other Community policies" (emphasis added). These provisions were strengthened further in Article 6 of the 1997 Amsterdam Treaty.

These EU developments, moreover, did not take place in a vacuum, but were also shaped in part by wider normative developments at the global level. Just as the Beijing Conference helped to introduce gender mainstreaming into the normative discourse of the EU, so the Union's push for environmental policy integration was reinforced, from the late 1980s onwards, by the related concept of "sustainable development." As first formulated by the Brundtland Commission in its 1987 report, Our Common World, sustainable development was seen to require a balance among economic, social and environmental concerns in development, as well as the adoption of an environmental perspective by sectoral policymakers. Sustainable development would later become a central normative pillar of the EU, including through incorporation in the Amsterdam Treaty, and in 2001 the European Council (2001) adopted a non-binding Sustainable Development Strategy (SDS). The relationship between the SDS and EPI has been complex. While some scholars, like Lenschow, present EPI as "a first-order operational principle to implement and institutionalize the idea of sustainable development" (Lenschow 2002b: 6), others point to the potential for confusion between two mandates that are both vague as well as often uncoordinated in practice (Pollemaerts et al. 2007).

Following these developments, most scholars agree that "EPI has become a firmly embedded normative principle in the EU acquis" (Lenschow 2002b: 5) and that the principle of integration is legally binding on EU institutions. However, the precise nature of this legal obligation (whether simply procedural or substantive in terms of policy outputs) remains unclear, and the established jurisprudence suggests that the ECJ would be reluctant to second-guess the political branches in the absence of major procedural violations or manifest errors of fact (Dhondt 2003). For this reason, the implementation of EPI in practice would be decided not in the courts but in the EU's political institutions, including, in the first instance, the various DGs and services of the Commission.

Yet, both EU practitioners and scholars recognized, the "roadblocks" (Lenschow 2002d) to successful environmental policy integration remained substantial. As Andrea Lenschow has observed, EPI "implies that policy-makers in the nonenvironmental sectors recognize the environmental repercussions of their decisions and adjust them when they undermine sustainable development"; yet, in the absence of a clear and enforceable mandate, "there remains ample room for sectoral policymakers to evade such substantive environmental responsibilities" (Lenschow 2002b: 7). Andrew Jordan et al. (2008: 165) go further, suggesting that, "very few EU-level actors are anywhere near as committed to EPI as DG Environment. In fact, many parts of the Commission regard it at best as essentially unimportant and at worst something to be neutered." 
The question, therefore, was how the Commission would structure the new EPI mandate to overcome such resistance. In this regard, David Wilkinson, in the first systematic study of EPI in the Commission, usefully distinguished between what he called "top-down" and "bottom-up" approaches to environmental policy integration. In Wilkinson's (1997: 155) words,

"Top-down" integration depends upon the possession and exercise, normally by an environment ministry, of formal power in relation to other departments... Mechanisms for enacting this approach include the development by the Government as a whole, perhaps led by an environment ministry, of sectoral Action Plans with quantified targets and timetables for reaching them.... Top-down integration requires effective review and reporting mechanisms to monitor progress in achieving targets.

By contrast, Wilkinson (1997: 156), continues,

A bottom-up approach to integration reflects the application of influence rather than formal power. Environment ministries or agencies are not able to impose constraints on the actions of other departments, which remain free to develop policies and programmes in light of their own sectoral priorities. The integration of environmental considerations into sectoral policies comes instead from a process, often very gradual, of cultural change in which sectoral departments themselves come to take greater account of environmental considerations. The role of environment ministries in this process is to influence and guide rather than direct [emphasis in original].

In practice, Wilkinson acknowledges, these two ideal types occupy extreme positions along an "integration continuum," similar to our continuum between hard and soft incentives referred to above.

In the case of the EU's EPI mandate, we concur with Wilkinson's (1997, 2007) assessment that the Commission has generally opted for a "bottom-up," "soft," or "new governance" approach to EPI, with a vague mandate, a weak coordinating role for DG Environment, and an almost complete absence of hard incentives for sectoral officials. The result, as we shall see, is a set of policy outputs that have been judged, by the Commission as well as by scholars and environmental activists, to fall well short of the professed goal of environmental policy integration.

\subsection{From Concept to Implementation: Soft EPI in the Commission, 1993-1998}

While EPI had been a nominal aim of the EU from the third EAP, the Commission made no effort to operationalize EPI through concrete actions until early 1993 . The specific guidelines, drawn up by DG Environment together with DG ADMIN and the Commission Secretariat General, were published as an internal document (Commission 1993b), and laid down a five-part plan for implementing EPI. First, a new "integration unit" would be established within DG Environment. Second, each sectoral DG was to designate an "integration correspondent" to liaise with DG Environment and to ensure that environmental concerns were integrated into sectoral policies. Third, policy proposals with "significant environmental effects" would be identified with a "green star" and subjected to a strategic environmental assessment 
(SEA). Fourth, each DG was to undertake an annual evaluation of its environmental performance, with the results to be published in the Commission's annual General Report on the Activities of the European Union. Fifth and finally, the Commission would draw up a "code of environmental conduct" for its own activities, including purchasing policy, waste minimization, and energy conservation (Commission 1993b).

So constituted, the Commission's first EPI effort looks broadly similar to the gender mainstreaming effort reviewed above-a "bottom-up," network approach with a weak central role for DG Environment in promoting, but not compelling, consideration of environmental issues by sectoral DGs. Wilkinson, in the most systematic analysis of these early efforts, uncovered a number of weaknesses in implementation. For example, while the various DGs did establish integration correspondents, in practice many of these correspondents delegated their environmental responsibilities to subordinates, and on the rare occasions when the integration correspondents met across departments, "a significant proportion failed to attend" (Wilkinson 1997: 162). The Commission system also left a substantial amount of discretion to individual DGs, which were, for example, delegated the responsibility to decide whether a given proposal would be subject to an environmental appraisal, with the result that no references to such appraisals could be found in any Commission documents several years after the start of the program (Wilkinson 1997: 163). With respect to reporting requirements, the Commission indicated that unpublished reports had been submitted by the various DGs following the first year of the program, "but to what extent and how the environment has been taken into account, on a systematic basis... is rarely indicated" (quoted in Wilkinson 2007), and no systematic account of this reporting was published by the Commission in the subsequent years, rendering moot any hope of "naming and shaming" DGs into compliance. The result of these efforts, Wilkinson (1997: 164) argues, was "modest":

Not all elements of the new integration procedures have been implemented, and where they have, their impact has been limited. Where substantive progress toward integration has occurred in the five key policy sectors identified in the 5EAP, this has been as much a consequence of exogenous factors as of the June 1993 measures.

A similar verdict appears in the Commission's own mid-term evaluation of the 5th EAP, which also points clearly to the program's reliance on soft incentives and persuasion:

The measures so far have had a limited impact... progress has varied according to sectors, but the message of the Fifth Programme has not been sufficiently integrated within the Commission. The process depends on persuasion and influence and will take time. In the longer term, change is likely to take place through increased education, training and changes in attitude. It will require continued adequate resources and sustained commitment (Commission 1996b; quoted in Wilkinson 1997: 164).

Other studies support Wilkinson's overall findings, with Jordan et al. (2008: 166) reporting that the integration unit of DG Environment was poorly resourced and never given authority to engage in a "policing role" vis-à-vis other DGs. Lenschow 
(2002b: 5) concurs, writing that, "Neither policy failure nor a paradigm shift led by the environment community made much of an impression on sectoral policymakers." Problems of implementation, Lenschow (2002d) argues, can be traced to specific "roadblocks," including opposition from sectoral officials and from interest groups fearing costs of new environmental regulations.

Sector-specific case studies reveal dramatic variations in policy outputs during this period. In some areas, individual DGs demonstrated progress in EPI, largely in response to external pressures. The Common Agricultural Policy (CAP), for example, had long been characterized by a sectorally isolated "iron triangle" of farming interests and had resisted EPI, yet the combination of budgetary limits and pressures from international trade partners contributed to the adoption of new "agri-environment" programs as part of the CAP reforms of the 1990s (Buller 2002). The EU's Structural Funds followed a similar trajectory, responding to pressure from environmentally conscious member states and the European Parliament by integrating environmental assessment into EUfunded projects and programs (Lenschow 2002c).

Despite these relative successes, the Commission's EPI agenda was taken up less readily by most other sectors, including the transport and energy sectors that together accounted for the overwhelming majority of the EU's contribution to environmental problems such as climate change. In transport, EPI met strong resistance in the Commission (Hey 2002: 137-138) and also in the Transport Council, which has been accused of having "the interests of the road haulage industry uppermost in mind" (Laubner 2002: 154). Similarly, in the energy sector, the Commission's and member states' first priority during the 1990s was energy market liberalization, and efforts by DG Environment to introduce EU measures on energy efficiency, renewables, and a possible carbon tax met with little success either within the Commission or in the Council of Ministers (Collier 2002).

\subsection{The Cardiff Process: High Level, Soft Incentives}

By the end of the 1990s, all of these weaknesses in the Commission's EPI program were evident, and proponents of integration began to push for a new approach. In 1998, the Commission (1998b) put forward a new initiative, entitled "A Partnership for Integration," that would draw in the other EU institutions, especially the various sectoral Councils of Ministers and the summit meetings of the European Council, into an extended EPI process.

Endorsed by the European Council at their June 1998 meeting in Cardiff, the socalled Cardiff Process "invite[d] all relevant formations of the Council to establish their own strategies for giving effect to environmental integration and sustainable development within their respective policy areas." The Cardiff mandate further "invited" the Council and Commission to "keep under review their organizational arrangements necessary to carry this forward" (European Council 1998). In concrete terms, the European Council invited the nine sectoral Council formations to prepare action plans for environmental policy integration.

Once again, however, this extraordinarily ambitious program, which sought to corral not just Commission bureaucrats but sectoral ministers from diverse member states, relied almost entirely on soft incentives. While the European Council was in principle leading the effort in the Cardiff process, in practice EPI was only one of many issues 
competing for the attention of the heads of state and government at their periodic summits, and Cardiff was prioritized by only a few environmentally activist member states during their rotating Council presidencies. In practice, the nine Council formations did eventually formulate a series of reports and strategies, but these were highly variable in quality and detail, with some offering "little more than a description of past policies, extant legislation, and new initiatives already in the pipeline" (Kraemer et al. 2001: 4; see also Fergusson et al. 2001, Wilkinson et al. 2002, European Environment Agency 2005: 34).

Faced with a flagging process, the European Council in 2003 asked the Commission to undertake an annual stocktaking of the Cardiff process for each year's spring summit. The following year, in 2004, the Commission produced a critical assessment, which surveyed the actions taken in each of the nine Councils selected for EPI. The report identified some areas of progress, including the 2003 CAP reforms as well as developments in the area of energy, where events were increasingly driven by the Union's global commitment to implement the Kyoto Protocol on climate change. Nevertheless, the Commission assessment joined scholarly evaluations in concluding that "the Cardiff process has failed to deliver fully on expectations." Among other flaws, the Commission noted "a general lack of consistency" across Council formations, with some adopting detailed strategies, while others "are limited to declarations of intent" (Commission 2004b: 31-32).

The Commission's assessment, however, seems to have had little or no impact on subsequent European Council meetings, which failed even to mention the Cardiff process in 2005 or 2006. By June 2005, the Director General of DG Environment publicly admitted that, "the Cardiff process is not going anywhere" (quoted in Jordan et al. 2008: 170). Indeed, scholars generally agree that sectoral coordination remains extremely weak among the nine current configurations of the Council (Hartlapp 2011), leaving the onus of implementing EPI primarily on the Commission.

\subsection{New Directions, 2002-2010}

Following these disappointing results, the Commission and other EU bodies have experimented with other potential mechanisms - including Thematic Strategies, a new "Lisbon Strategy," and a new "impact assessment" procedure-for EPI in the 2000s. By and large, however, these efforts have been hampered by two key features. First, most of these efforts have been "soft" along the dimensions specified above, which has limited their impact in sectoral DGs and Council formations. Second, these various procedures have forced environmental officials to participate in cross-sectoral groups and networks in which the environment is not the primary policy consideration. Indeed, many scholars have identified a shift over the past decade, in which cross-cutting mandates increasingly emphasize economic competitiveness as the overriding policy concern, relegating environmental and other considerations to secondary status.

\subsubsection{The Sixth EAP and the Thematic Strategies}

The decade between the fifth EAP, adopted in 1992, and the sixth, adopted in 2002, had witnessed a sustained effort by the Commission to promote EPI, only to see both 
its internal reforms and the Cardiff process falter. The sixth EAP, in this context, retained EPI as an ambition (European Union 2002), but proposed to pursue that ambition through yet another, "radically different" (Wilkinson 2007: 5) form, namely the creation of a series of "Thematic Strategies" (TSs) that would bring together policy makers across multiple issue-areas, in an attempt to formulate coherent, integrated policies with respect to seven cross-cutting issues: air pollution, waste prevention and recycling, the marine environment, soil, pesticides, natural resources, and the urban environment.

In principle, Ingmar von Homeyer (2007: 8) points out in an excellent study, the Thematic Strategies might be expected to offer an ideal forum for environmental policy integration. And indeed, the strategies, elaborated between 2002 and 2006, were formulated in large part through inter-service committees and working groups, and following extensive consultation with member-state officials, industry, and other civil-society groups (Homeyer 2007: 16). And yet, Homeyer and other scholars find, the process of extensive inter-service and civil-society consultation resulted in each case in a very substantial weakening of the Commission's original proposals, which in all but one case (air pollution) lacked the specific targets called for in the 6th EAP (Homeyer 2007: 8, 18). Indeed, the various Thematic Strategies employ mostly softlaw, "new governance" instruments, with few proposals for binding regulations. Of the seven TSs, five called only for "framework" directives, which provide member states with unusually great leeway in implementation, and two others called for no legally binding legislation at all (Homeyer 2007: 10).

In light of this evidence, Wilkinson (2007: 3) has claimed that the disappointing terms and implementation of the TSs "derive from the very logic of EPI, which ultimately foresees a sharing of responsibility for the development of environmentrelated policies with non-environmental actors." In fact, we would suggest, the Thematic Strategies differ fundamentally from the Commission's original EPI mandate, and indeed from the other cross-cutting mandates considered in this article, all of which place what Lafferty and Hovden (2003: 9) call "principled priority" on a particular policy concern, such as the environment, which other sectoral DGs are expected to take on board. By contrast, the inter-service groups formed under the Thematic Strategies placed no such priority on the environment per se, reducing DG Environment to one among many DGs, forced to defend environmental considerations against competing sectoral concerns. Indeed, this was to be the pattern for other initiatives later in the decade, with similar results.

\subsubsection{The Lisbon Strategy and the Environment}

Just as environmental policy cannot be considered in isolation from other sectors, so a discussion of EPI cannot ignore another, and largely competing, EU mandate, the Lisbon Strategy for Jobs and Growth. So called because of its beginnings at the Lisbon European Council meeting in March 2000, the Lisbon Strategy set the goal to "make Europe, by 2010, the most competitive and the most dynamic knowledge-based economy in the world," reflecting widespread concerns about the economic decline of the EU relative to a revitalized United States and fast-growing powers like China and India. In addition to its ambitious aims, the Lisbon Strategy is perhaps best known for the means by which the Union aimed to achieve its goal: the so-called Open Method of 
Coordination (OMC). This is a non-binding form of policy coordination, based on the collective establishment of policy guidelines, targets, and benchmarks, coupled with a system of periodic "peer review" in which member governments present their respective national programs for comment by their EU counterparts.

Although typically identified as an example of "soft law" and "new governance" and assailed as a largely failed experiment in both (Rhodes and Citi 2007), the Lisbon Strategy in fact falls closer to the "hard" end of Abbott and Snidal's continuum than either the gender mainstreaming or EPI mandates, requiring as it does annual reporting of national action plans as well as peer review and Commission critique of each member state's plans. Just as importantly for our purposes here, while the Lisbon Strategy was intended to incorporate environmental objectives, it rapidly became clear that environmental considerations took a back seat in the Lisbon guidelines to jobs and growth - a priority that was made explicit by the reform of the Strategy in 2005 to highlight jobs and growth over sustainability as the core aim of the effort (Jordan et al. 2008). Despite its nominal inclusion of sustainable development considerations, the Lisbon Strategy would not prove to be an engine for environmental policy integration.

\subsubsection{Impact Assessment}

We have already alluded to the use of strategic environmental assessments as potential tools for EPI, noting that the use of these tools in preparing Commission proposals had generally been voluntary and limited. In recent years, however, the Commission has embraced a broader cross-cutting mandate for "integrated" impact assessment (IA), in which significant policy proposals would be subject to prior assessment across a range of economic, social and environmental criteria. In the context of this study, IA represents a comparatively, and increasingly, "hard" instrument for mainstreaming multiple criteria in all EU policies - although the specific place of environmental considerations in IA, as in the Lisbon Strategy, remains unclear.

The lineage of impact assessment can be traced in part to early use of environmental impact assessment in the United States and Europe, but also to the requirement, first imposed by the Reagan Administration, that US regulatory agencies undertake Regulatory Impact Assessments (RIAs) to weigh the costs and benefits of proposed new regulations. By the mid-1990s, this OECD had established guidelines for best practice in impact assessment, and by the 2000s every EU member state had put in place some version of impact assessment. ${ }^{11}$

The push for integrated impact assessment at the EU level took place in the early 2000s, shaped both by the 2001 Sustainable Development Strategy and by the Commission's "Better Regulation" agenda, adopted in response to criticisms of overregulation from Brussels (Franz and Kirkpatrick 2007: 145). As laid out in the Commission's 2002 communication on impact assessment, the new IA procedures

\footnotetext{
${ }^{11}$ The scholarly literature on impact assessment has grown dramatically in recent years. For an excellent review, see Radaelli and De Francesco (2010). Studies of EU impact assessment have also grown dramatically; see, e.g., the excellent analyses by Renda (2006), Cecot et al. (2008), Meuwese (2008), and Bäcklund (2009). Several studies have focused specifically on the place of environmental considerations in Commission IA; see, e.g., Wilkinson et al. (2004), Franz and Kirkpatrick (2007), and Ruddy and Hilty (2008)
} 
were intended to replace all previous single-issue assessments and assess the potential economic, social and environmental impacts of significant proposed legislation, regulations, and policy proposals. Following the SDS, impact assessments were expected to be "balanced" among the three fields (a point to which we shall return presently). In terms of coverage, the new IA system would be mandatory for all items mentioned in the Commission's annual legislative work program as well as for other potential high-impact proposals and regulations to be identified by the Commission (Commission 2002).

In terms of the actual procedure, the Commission's original 2002 framework provided that the lead DG on any given proposal should also take the lead in preparing a "preliminary" IA, possibly with the support of an inter-service support group. This preliminary IA would then be submitted to the full College of Commissioners, which could ask for an "extended" IA for proposals likely to have major economic, social and/or environmental impacts. ${ }^{12}$ Commission DGs would be guided in the conduct of IAs by a series of Guidelines, published in 2002 and revised in 2005, 2006, and 2009.

The objectives of the new impact assessment were multiple (Bäcklund 2009), including, inter alia: improving the quality of EU regulation by providing precise analyses of the direct and indirect impacts of proposed policies as well as of alternative policy options; improving inter-departmental coordination within the Commission; and increasing the transparency and legitimacy of EU regulation by incorporating multiple stakeholders and making all impact assessments publicly available on the Commission's impact assessment website. ${ }^{13}$ From our perspective in this article, the institutional rules for impact assessment were "harder" than the Commission's earlier EPI mandate, since IAs were mandatory for at least the major proposals included in the Commission's annual work program, and no longer left to the discretion of the various DGs and services. Nevertheless, the IA system established in 2002 was still "soft" along a number of dimensions. At least initially, the lead DG for a given proposal was assigned the lead role in preparing IAs, with only weak provisions on inter-service coordination, which remained optional. Furthermore, the initial IA Guidelines lacked precise instructions for DGs, implicitly giving wide discretion to the services preparing the assessments. Finally, by contrast with the US system, where the Office of Management and Budget (OMB) provided a centralized and hierarchical quality-control system for RIAs coming from executive agencies, the EU system was more decentralized, with the Commission Secretariat General given the power to establish and revise the IA Guidelines but not to police the quality of assessments (The Evaluation Partnership 2007: 13).

Perhaps not surprisingly in light of these features, early evaluations of EU impact assessments during the first several years (2003-2005) were largely critical, with several content analyses finding that the first IAs following the adoption of the new mandate rarely offered quantitative and monetized assessments, often failed to consider the costs and benefits of alternative approaches, and considered the benefits of proposed policies more consistently than the costs (Wilkinson et al. 2004; Lee and

\footnotetext{
${ }^{12}$ This terminology would later be changed, with the first analysis relabeled as "road maps," to be followed in all cases by full "impact assessments."

${ }^{13} \mathrm{See}$ http://ec.europa.eu/governance/impact/ia_carried_out/cia_2010_en.htm.
} 
Kirkpatrick 2006; Renda 2006). In 2006, the Commission commissioned an external evaluation of the IA program, which identified a number of weaknesses in both the process and the content of the IAs adopted during the first 3 years of the program, and proposed a number of reforms, including the establishment of "sufficient sanctioning mechanisms" to impose quality controls on the various DGs and services (The Evaluation Partnership 2007: 14).

Indeed, one of the most striking features of EU impact assessment is the extent to which the Commission has repeatedly reformed and "hardened" the process, offering stronger centralized control, clearer guidance, harder incentives, greater accountability, and greater administrative capacity over time. For example, the Commission issued revised Guidelines for impact assessment in 2005, 2006 and 2009, progressively clarifying procedures for the services in preparing IA, including the requirement to establish mandatory Inter-Service Steering Groups (ISSGs) for each assessment.

Perhaps most significantly, the Commission introduced, in November 2006, a new, five-member Impact Assessment Board (IAB), whose members serve in their personal capacity and answer only to the President of the Commission. The primary purpose of the Board, according to its mandate, is to improve the quality of Commission impact assessments, primarily through its review mechanism whereby the Board reviews and comments on draft IAs and may request resubmission of IAs deemed to suffer from serious problems. The Board, as the Commission admitted in its 2010 annual review, does not have the statutory right "to block a proposal from being submitted for political examination because the impact assessment is of insufficient quality."

The Commission is, however, fully informed about Board opinions. The fact that the Board's opinions are formally part of Commission decision-making procedures and are published provides an incentive for Commission services to make the improvements to the impact assessments that the Board recommends (Commission 2010: 19).

In practice, the IAB has operated in large part as a force for centralization in which the center-right Commission of President José Manuel Barroso has imposed his better regulation agenda on potentially reluctant Commission services. In the words of one senior Commission official, "these are all Barroso's people and they can stop anything" (quoted in Peterson 2008: 764)

Concretely, the Board engages in mandatory review of each and every draft impact assessment prepared in the various DGs and services, and it has been increasingly bold in returning draft IAs to the services for revisions - with $37 \%$ of all draft IAs thus subject to revision in 2009, and with all Commission services required to explain in their revised IAs how they have incorporated the Board's recommendations (Commission 2010: 6, 12). The Board has also, in a series of annual reports and revised guidelines, called for greater quantification of costs and benefits, more open consultation with stakeholders, and greater clarity in the presentation of findings in executive summaries. By contrast with the weak or nonexistent coordinating roles of DG Employment and Social Affairs and DG Environment in the gender mainstreaming and EPI cases, respectively, the IAB enjoys strong coordinating powers and brandishes hard incentives over sectoral DGs. 
Although the IAB has been in operation for only 3 years at this writing, early evidence from scholarship and from the Commission's own reports suggests that the practice of impact assessment in the Commission has improved in ways sought by the Board. In its 2010 report, the IAB finds a general improvement in the quality of IAs across the board (Commission 2010: 13). In addition, the Board identifies a number of procedural steps taken within and across DGs "to strengthen the impact assessment culture in services," including strengthening of IA units and procedures in individual DGs; increased IA training for new and existing Commission officials; improved operation of the ISSGs; and the establishment of an inter-service Impact Assessment Working Group that met three times during 2009 (Commission 2010: 15). Along similar lines, a scholarly assessment of IAs undertaken since the 2005 reforms found a gradual improvement in the quality of IAs, which rivaled that of US RIAs for proposals estimated to have high impacts (Cecot et al. 2008). The reforms of the IA process, and indeed the process itself, have had only a few years to operate, but early indications are that the hardening of the process has already yielded greater efficiency over time.

However, it is less clear that IA has operated as an effective tool of environmental policy integration. Several years after the inception of the IA system, several scholarly analyses criticized the Commission's 2002 Guidelines, contending that the indicators for economic impact were set down with far greater clarity than those for environmental or social impacts. Content analysis of the early IAs, moreover, found that the analyses were unbalanced, with environmental and social effects analyzed in less detail than economic impacts, or not at all (Wilkinson et al. 2004, IMV 2006). There is, in the view of many authors, a fundamental tension in the EU impact assessment system, which is simultaneously supposed to operationalize the EU's Sustainable Development Strategy, on the one hand, while at the same time simplifying and reducing the administrative costs of regulation in line with the Lisbon Strategy and the Better Regulation initiative-with the latter reportedly dominating the process during its early years (Ruddy and Hilty 2008: 93).

Moreover, by comparison with general assessments of the IA system, which find improvements over time, recent scholarly studies suggest that the integration of environmental considerations may have actually worsened over time (Wilkinson 2007). The revised Guidelines, for example, have placed progressively greater emphasis on the economic aspects of impact assessment, while doing comparatively little to strengthen or clarify the rules relating to environmental concerns, leading some scholars to conclude that the reformed IA system systematically privileges jobs and growth over environmental considerations. Franz and Kirkpatrick (2007: 153, 155), for example, undertook a content analysis of a sample of 13 impact assessments undertaken after the 2005 reforms, and found that economic impact received "high coverage" in 10 out of 13 assessments, while only 5 assessments gave any consideration at all to environmental impact, and only 3 of those in any detail. Environmental sustainability, they conclude, remains "poorly considered" in the post-reform IAs.

In sum, the EU's commitment to environmental policy integration is one of the longest-running cross-cutting mandates in any international organization, running across several decades and a number of distinct initiatives within and outside the Commission. As with our examination of the gender mainstreaming mandate above, 
however, most of these efforts have relied on soft incentives, favoring "persuasion rather than power" in the effort to change the behavior of sectoral policy-makers (Wilkinson 1998: 113), the primary exception being the relatively new impact assessment procedure. Indeed, Wilkinson (2007: 7) argues, "EU environmental policy seems to be retreating increasingly into the realm of soft instruments inspired by the open method of coordination." Wilkinson leaves open the possibility that "soft" approaches may eventually yield results, calling for more research into the question, yet he concludes that, "unless there are 'win-win' opportunities or external pressures that provide incentives to specific 'sectoral' DGs to integrate environmental considerations, such new modes of governance are likely to have limited effectiveness" (Wilkinson 2007: 8). In terms of outcomes, finally, it is difficult to disagree with the Commission's assessment that, "There has been only limited progress with the fundamental issues of integrating environmental concerns into other policy areas" (Commission 2007c: 17), or with the conclusion by Jordan et al.'s (2008: 172) that, "Whichever way you look at it, the environmental sector has largely failed to get the sectors to 'own' (let alone implement) EPI."14

\section{Conclusions: Institutional Design and IO Performance}

In this article, we identified the policy-making challenges for international organizations of cross-cutting mandates; we hypothesized that such mandates are more likely to produce consistent IO performance where central policy-makers employ hard incentives to motivate sectoral officials to accept them; and we sought to test our hypothesis on two case studies, of gender mainstreaming and environmental policy integration, with more brief discussions of two parallel mandates, for equal opportunities and impact assessment, respectively. We conclude here, very briefly, with five observations, the first two relating directly to our core hypothesis, and the last three extensions and questions for future research.

First, as we have seen, the leaders of the European Union have placed much of their policy emphasis and many of their hopes over the past two decades on the development of two cross-cutting mandates, gender mainstreaming and EPI, yet those same leaders have relied overwhelmingly on what we have called soft incentives to get sectoral policy-makers to accept and implement these new mandates. In both cases, however, the result has been a highly variable and generally disappointing pattern of implementation and policy outputs, with some DGs and services mainstreaming gender and integrating environmental concerns into their policy-making, but with many other DGs undertaking no or only token efforts to do so.

Second, within each of our case studies we have examined related efforts to implement an internal equal opportunities mandate as well as integrated impact assessment across all the Commission services, in both cases adopting a more centralized and hierarchical approach in which a central authority (DG Administration in equal opportunities, the Secretariat General and the Impact Assessment Board for IA)

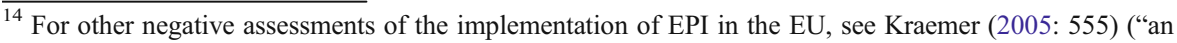
empty shell which has not had much substantive content"), and Herodes et al. (2007).
} 
was able to impose a clear mandate with targets and deadlines, require annual reporting, and employ both material and social pressures to induce conformity. In both cases, moreover, cross-cutting mandates were hardened over time, with clear improvements in IO performance following reforms. Of course, these findings concern only a single international organization, the EU, and should be subject to further testing on other cross-cutting mandates and in other international organizations. Nevertheless, our core hypothesis that IO performance on cross-cutting mandates depends in large part on the use of hard incentives for IO officials is strongly supported across all of our cases.

Third, while we have generally attempted to present each of our cross-cutting mandates as a free-standing project, one of the most striking findings of our research is the proliferation of a growing number of cross-cutting mandates, many of which overlap with no clear hierarchy or coordination among them. This phenomenon, sometimes referred to as the "mainstreaming of mainstreaming" in EU circles, threatens to overwhelm sectoral EU officials with a large number of often vague or even contradictory mandates, which may in turn threaten IO performance in the future. The Commission's “integrated" impact assessment effort can be seen in this light, as an effort to collapse or combine several cross-cutting aims into a single instrument, and holds promise in that regard. Yet such a super-mandate also presents often unacknowledged trade-offs among multiple policy aims, and it remains unclear whether both environmental and gender concerns are being edged aside in favor of policy-makers' concerns about economic competitiveness, which arguably enjoy "principled priority" in contemporary EU policy-making.

Fourth, as the Lisbon Strategy and the impact assessment project make clear, institutional design matters not simply in the choice of hard or soft incentives, but in more subtle ways as well. In the original conception of the gender mainstreaming, equal opportunities, and EPI mandates, the essential formula was the same: to identify a crosscutting policy concern, identify it as a priority issue for all units of government, and establish mechanisms (whether hard or soft) to diffuse that concern from an existing center to sectoral policymakers. By contrast, the environmental policy integration experiments of the past decade have involved cross-sectoral coordination in which DG Environment was reduced to at best a first-among-equals with other DGs, and in which the environment was one of many policy concerns, often subordinated in practice to the competing concern with economic competitiveness. Put simply, the institutional form of cross-cutting mandates is likely to shape outcomes not just by establishing hard or soft incentives, but also by determining which policy considerations, if any, receive "principled priority."

This raises a fifth and final point, which we have bracketed until now, namely that such institutional choices are themselves endogenous to the preferences of the actorsprimarily the member states, but also and to varying extents supranational actors like the Commission and the European Parliament-with influence over the institutional form of cross-cutting mandate. In this context, the relative weaknesses of the gender mainstreaming and EPI mandates, the extensive use of soft incentives in these areas, and the subordination of environmental and gender concerns to jobs and growth in the Lisbon Strategy and impact assessment, all point to the conclusion that the most important political actors in the EU have chosen not to adopt the procedural and institutional forms that, official and scholarly evaluations suggest, are most likely to produce policy outputs in line with the Union's stated social and environmental goals. 
From a normative perspective, we see a consistent call among women's groups (European Women's Lobby 2007) and environmental advocates (Wilkinson 2007) for the Union to adopt more "hierarchical," "harder," and "top-down" approaches to gender mainstreaming and EPI, respectively. From a positive social-science perspective, this observation calls our attention to the need for additional studies of the institutional design choices of states and other actors who establish the institutional frameworks for the implementation of cross-cutting mandates in domestic and international governance.

Acknowledgements The authors would like to thank Tamar Gutner, Dorte Sindbjerg Martinsen, Alex Thompson, and two anonymous reviewers for comments on previous drafts of this article.

Open Access This article is distributed under the terms of the Creative Commons Attribution Noncommercial License which permits any noncommercial use, distribution, and reproduction in any medium, provided the original author(s) and source are credited.

\section{References}

Abbott, K. W., \& Snidal, D. (2000). Hard and soft law in international governance. International Organization, 54(3), 421-456.

Bäcklund, A. (2009). Impact assessment in the European Commission - a system with multiple objectives. Environmental Science \& Policy, 12(8), 1077-1087.

Buller, H. (2002). Integrating European Union environmental and agricultural policy. In A. Lenschow (Ed.), Environmental policy integration: Greening sectoral policies in Europe (pp. 103-126). London: Earthscan.

Cecot, C., Hahn, R., Renda, A., \& Schrefler, L. (2008). An evaluation of the quality of impact assessment in the European Union with lessons for the US and the EU. Regulation and Governance, 2(4), 405-424.

Checkel, J. T. (2005). International institutions and socialization in Europe: introduction and framework. International Organization, 59(4), 801-826.

Collier, U. (2002). European Union energy policy in a changing climate. In A. Lenschow (Ed.), Environmental policy integration: Greening sectoral policies in Europe (pp. 175-192). London: Earthscan.

Commission of the European Communities (1983). Third programme of action on the environment (1982-86). Official Journal of the European Communities, C46, 17.02.83.

Commission of the European Communities (1987). Fourth programme of action on the environment (1987-92). Official Journal of the European Communities, C328, 7.12.87.

Commission of the European Communities (1993a). Fifth programme of action on the environment (1993-2000). Official Journal of the European Communities, C138, 17.05.93.

Commission of the European Communities (1993b). Integration by the Commission of the environment into other policies, SEC(93)785/5.

Commission of the European Communities (1996a). Communication from the Commission: Incorporating equal opportunities for women and men into all community policies and activities, COM(96)67 final.

Commission of the European Communities (1996b). Progress report from the Commission on the implementation of the European community programme of policy and action in relation to the environment and sustainable development towards sustainability, $\operatorname{COM}(95) 62$ final.

Commission of the European Communities (1998a). Progress report from the Commission on the follow-up of the communication: Incorporating equal opportunities for women and men into all community policies and activities, $\operatorname{COM}(98) 122$ final.

Commission of the European Communities (1998b). Commission communication to the European council: Partnership for integration — a strategy for integrating environment into European Union policies, COM(98)333 final.

Commission of the European Communities (2002). Communication from the Commission on impact assessment, $\operatorname{COM}(2002) 0276$ final. 
Commission of the European Communities. (2004a). Fourth action programme for equal opportunities for women and men at the European Commission. Brussels: DG ADMIN.

Commission of the European Communities (2004b). Commission working document: Integrating environmental considerations in other policy areas - a stocktaking of the Cardiff process, COM(2004)394 final.

Commission of the European Communities (2007a). Document de travail des services de la Commission. Feuille de route pour l'égalité entre les femmes et les homes 2006-2010. Programme de travail: réalisations 2006 et prévisions 2007, $\mathrm{SEC}(2007) 537$.

Commission of the European Communities (2007b). Memorandum to the Commission of 2nd May 2007 on the targets for the recruitment and appointment of women to management and other $\mathrm{AD}$ posts in the Commission for the year 2007 (Memorandum from Vice-President S. KALLAS), SEC(2007)507/4 and/5.

Commission of the European Communities (2007c). Communication from the Commission to the European parliament, the European economic and social committee and the committee of the regions on the midterm review of the sixth community environment action programme, SEC(2007)546 and SEC(2007)547.

Commission of the European Communities (2008a). Document de travail des services de la Commission. Feuille de route pour l'égalité entre les femmes et les homes 2006-2010. Programme de travail: réalisations 2007 et prévisions 2008, SEC(2008)338.

Commission of the European Communities (2008b). Memorandum to the Commission of 14th May 2008 on the targets and appointment of women to management and other $\mathrm{AD}$ posts at the Commission for 2008, SEC(2008)1864/3.

Commission of the European Communities (2008c). Employment, social affairs \& equal opportunities: Gender equality, gender mainstreaming intro practice. http://ec.europa.eu/employment_social/gender_equality/ gender_mainstreaming/practice_en.html. Accessed 22 February 2007.

Commission of the European Communities (2010). Commission staff working document: Impact assessment board report for 2009, SEC(2009)1728 final.

Council of Europe (2008). Gender mainstreaming. http://www.coe.int/T/E/Human_Rights/Equality/ 02._Gender_mainstreaming/. Accessed 18 March 2008.

Dhondt, N. (2003). Integration of environmental protection into other EC policies: Legal theory and practice. Groeningen: Europa Law Publishing.

European Council (1998). Presidency conclusions: Cardiff European Council, 15-16 June, Brussels.

European Council (2001). Presidency conclusions: Göteborg European Council, 15 and 16 June 2001, Brussels.

European Environment Agency (2005). Environmental policy integration in Europe: State of play and an evaluation framework, EEA Technical Report No. 2/2005.

European Union (2002). Decision No. 1600/2002/EC of the European parliament and of the council of 22 July 2002 laying down the sixth community environmental action programme, Official Journal of the European Union L 242/1.

European Women's Lobby (2007). Evaluation of the implementation of the European Commission's roadmap for equality between women and men, 2006-2010-Year One, http://www.womenlobby.org/ site $/ 1$ abstract.asp?DocID $=2040 \& v 1 \mathrm{ID}=\& \mathrm{RevID}=\&$ namePage $=$ \&pageParent $=\& D o c I D \_s o u s m e n u=\&$ parentCat=15. Accessed 18 March 2008.

Fergusson, M., Coffey, C., Wilkinson, D., \& Baldock, D. (2001). The effectiveness of EU council integration strategies and options for carrying forward the "Cardiff" process. London: Institute for European Environmental Policy.

Franz, J., \& Kirkpatrick, C. (2007). Integrating sustainable development into European policy making: the role of impact assessment. Journal of Environmental Assessment Policy and Management, 9(2), 141-160.

George, A. L., \& Bennett, A. (2005). Case studies and theory development in the social science. Cambridge: MIT Press.

Gutner, T. (2002). Banking on the environment: Multilateral development banks and their environmental performance in Central and Eastern Europe. Cambridge: MIT Press.

Gutner, T., \& Thompson, A. (2010). The politics of IO performance: A framework. Review of International Organizations, 5(3) doi:10.1007/s11558-010-9096-Z.

Hafner-Burton, E. M., \& Pollack, M. A. (2002). Mainstreaming gender in global governance. European Journal of International Relations, 8(3), 339-373.

Hafner-Burton, E. M., \& Pollack, M. A. (2009). Mainstreaming Gender in the European Union: Getting the Incentives Right. Comparative European Politics, 7(1), 114-138.

Hartlapp, M. (2011). Organizing exits from the joint-decision trap? Cross-sectoral (non-)coordination in the European Union. In G. Falkner (Ed.), The EU's decision traps: Comparing policies. Oxford: Oxford University Press.

Hawkins, D., Lake, D. A., Nielsen, D., \& Tierney, M. J. (Eds.). (2006). Delegation and agency in international organizations. New York: Cambridge University Press. 
Herodes, M., Adelle, C., \& Pollemaerts, M. (2007). Environmental policy integration at the EU level-a literature review, EPIGOV Paper No. 5. ecologic-Institute for international and European environmental policy.

Hey, C. (2002). Why does environmental policy integration fail? The case of environmental taxation for heavy goods vehicles. In A. Lenschow (Ed.), Environmental policy integration: Greening sectoral policies in Europe (pp. 127-152). London: Earthscan.

Homeyer, I. (2007). The Thematic Strategies: Governance for Environmental Policy Integration? EPIGOV Paper No. 8, Ecologic -Institute for International and European Environmental Policy, Berlin.

Hooghe, L. (2001). The European Commission and the integration of Europe. New York: Cambridge University Press.

Hoskyns, C. (1996). Integrating gender: Women, law and politics in the European Union. London: Verso.

Johnston, A. I. (2001). Treating international institutions as social environments. International Studies Quarterly, 45(4), 487-515.

Jordan, A., \& Lenschow, A. (Eds.). (2008). Innovation in environmental policy? Integrating the environment for sustainability. Cheltenham: Edward Elgar.

Jordan, A., Schout, A., \& Unfried, M. (2008). The European Union. In A. Jordan \& A. Lenschow (Eds.), Innovation in environmental policy? Integrating the environment for sustainability (pp. 159-179). Cheltenham: Edward Elgar.

Kraemer, L. (2005). The Dispersion of Authority in the European Union and its Impact on Environmental Legislation. In F. Wijen, K. Zoeteman, and J. Pieters (eds.), A Handbook of Globalization and Environmental Policy (pp. 545-68). Cheltenham: Edward Elgar.

Kraemer, R. A., Busgen, U., Choudhury, K., Klasing, K., Mazurek, A., Pfahl, S., et al. (2001). Results of the "Cardiff-processes": Assessing the state of development and charting the way ahead. Report to the German federal ministry for the environment. Nature conservation and nuclear safety.

Lafferty, W. L., \& Hovden, E. (2003). Environmental policy integration: towards an analytical framework. Environmental Politics, 12(3), 1-22.

Laubner, V. (2002). The sustainability of freight traffic across the Alps: European Union policy in controversies on transit traffic. In A. Lenschow (Ed.), Environmental policy integration: Greening sectoral policies in Europe (pp. 153-174). London: Earthscan.

Lee, N., \& Kirkpatrick, C. (2006). Evidence-based policy-making in Europe: an evaluation of European Commission integrated impact assessments. Impact Assessment and Project Appraisal, 24(1), 23-33.

Lenschow, A. (Ed.). (2002a). Environmental policy integration: Greening sectoral policies in Europe. London: Earthscan.

Lenschow, A. (2002b). Greening the European Union: An introduction. In A. Lenschow (Ed.), Environmental policy integration greening sectoral policies in Europe (pp. 3-21). London: Earthscan.

Lenschow, A. (2002c). Dynamics in a multi-level polity: Greening the EU regional and cohesion funds. In A. Lenschow (Ed.), Environmental policy integration: Greening sectoral policies in Europe (pp. 193218). London: Earthscan.

Lenschow, A. (2002d). Conclusion: What are the bottlenecks and where are the opportunities for greening the EU? In A. Lenschow (Ed.), Environmental policy integration: Greening sectoral policies in Europe (pp. 219-233). London: Earthscan.

Lenschow, A. (2010). Environmental policy: Contending dynamics of policy change. In H. Wallace, M. A. Pollack, \& A. R. Young (Eds.), Policy-making in the European Union (6th ed., pp. 307-330). Oxford: Oxford University Press.

Meuwese, A. C. M. (2008). Impact assessment in EU lawmaking. Kluwer Law International.

Nielsen, D. L., \& Tierney, M. J. (2003). Delegation to international organizations: agency theory and World Bank environmental reform. International Organization, 57(2), 241-276.

Nilsson, M., \& Eckerberg, K. (2007). Environmental policy integration in practice: Shaping institutions for learning. London: Earthscan.

Persson, Å. (2004). Environmental policy integration: An introduction. Policy integration for sustainability (PINTS) background paper. Stockholm: Stockholm Environment Institute.

Peterson, J. (2008). Enlargement, reform and the European Commission: weathering the perfect storm? Journal of European Public Policy, 15(5), 761-780.

Pollack, M. A., \& Hafner-Burton, E. M. (2000). Mainstreaming gender in the European Union. Journal of European Public Policy, 7(4), 432-456.

Pollemaerts, M., Herodes, M., \& Adelle, C. (2007). Does the EU sustainable development strategy contribute to EPI? Berlin: Ecologic. 
Radaelli, C., \& De Francesco, F. (2010). Regulatory impact assessment. In M. Cave, R. Baldwin, \& M. Lodge (Eds.), The Oxford handbook of regulation. Oxford: Oxford University Press.

Renda, A. (2006). Impact assessment in the EU: The state of the art and the art of the state. Brussels: Centre for European Policy Studies.

Rhodes, M., \& Citi, M. (2007). New modes of governance in the European Union: A critical survey and analysis. In K. E. Jørgensen, M. A. Pollack, \& B. Rosamond (Eds.), The handbook of European Union politics (pp. 463-482). New York: Sage.

Risse, T. (2000). "Let's argue!" communicative action and world politics. International Organization, 54 (1), 1-39.

Ruddy, T. F., \& Hilty, L. M. (2008). Impact assessment and policy learning in the European Commission. Environmental Impact Assessment Review, 28(2-3), 90-105.

Schimmelfennig, F., \& Sedelmeier, U. (Eds.). (2005). The Europeanization of Central and Eastern Europe. Ithaca: Cornell University Press.

Schmidt, V. (2005). Gender mainstreaming - an innovation in Europe? The institutionalisation of gender mainstreaming in the European Commission. Opladen: Barbara Budrich.

Stratigaki, M. (2005). Gender mainstreaming vs. positive action: an ongoing conflict in EU gender equality policy. European Journal of Women's Studies, 12(2), 165-186.

The Evaluation Partnership (2007). Evaluation of the Commission's impact assessment system. Final Report, April, http://ec.europa.eu/governance/impact/docs/key_docs/tep_eias_final_report.pdf. Accessed 27 June 2010.

Weaver, C. (2008). The strategic construction of the World Bank's gender and development agenda, paper presented at the international studies association annual meeting, San Francisco, CA, 25 March.

Wilkinson, D. (1997). Towards sustainability in the European Union? Steps within the European Commission towards integrating the environment into other European Union policy sectors. Environmental Politics, 6(1), 153-173.

Wilkinson, D. (1998). Steps toward integration the environment into other EU policy sectors. In T. O'Riordan \& H. Voisey (Eds.), The transition to sustainability (pp. 113-129). London: Earthscan.

Wilkinson, D. (2007). EPI at EU level, EPIGOV state of the art report. Berlin: Ecologic.

Wilkinson, D., Skinner, J., \& Ferguson, M. (2002). The future of the Cardiff process. London: Institute for European Environmental Policy.

Wilkinson, D., et al. (2004). Sustainable development in the European Commission's integrated impact assessment for 2003. London: Institute for European Environmental Policy.

Zürn, M., \& Checkel, J. T. (2005). Getting socialized to build bridges: constructivism and rationalism, Europe and the nation-state. International Organization, 59(4), 1045-1079. 